\title{
A Healthy City Project: A Case Study of Wonju City, South Korea and its Relevance to the Cities in Nepal
}

\author{
Sharma $\mathrm{B}^{1,2}, \mathrm{Nam}_{\mathrm{EW}} \mathrm{W}^{1,2^{*}}$ \\ 'Healthy City Research Center, Yonsei University, Wonju, South Korea, \\ ${ }^{2}$ Department of Health Administration, Graduate School, Yonsei University, Wonju, South Korea
}

\author{
Keywords \\ Case study, Developing countries, \\ Healthy City, Nepal, Wonju. \\ Corresponding author \\ Eun Woo Nam \\ Yonseidae-gil, Wonju-City, Gangwon-Do, \\ 26493, Republic of Korea \\ E-mail: ewnam@yonsei.ac.kr \\ Ms Bimala Sharma \\ E-mail: bimalasharma@gmail.com
}

\begin{abstract}
Introduction: One of the goals of sustainable development is to make cities inclusive, safe, resilient and sustainable. The healthy city approach is becoming increasingly important in addressing a large number of urban health problems and promoting healthy lifestyles in city dwellers.
\end{abstract}

Objectives: We performed a case study of the healthy city project in Wonju, South Korea to find out its characteristics and approaches, and to explore its relevance to the cities in Nepal.

Methods: We conducted a case study of the healthy city Wonju project by reviewing relevant published articles and web pages of the city (http://healthycity.wonju.go.kr), alliance for healthy cities, Korean statistical information service and World Health Organization. We also reviewed articles and documents related to healthy cities in South-East Asian countries and Nepal.

Results: The healthy city Wonju project, started in 2004, executed its five-year plan between 2006 and 2010, and is currently running with its 10 year long-term plan (2011- 2020). For its success, Wonju City has been awarded six times by WHO. Recently, Wonju city organized the seventh global conference of the AFHC in August, 2016 in Wonju with the main theme of "our cities, our health, our future". Key features of the healthy city Wonju project included: Strong political commitment of local government, financing the healthy city initiative with tobacco consumption tax, partnerships with universities, well organized healthy city teams under city administration, coordination with national and regional healthy cities alliance, community participation, and involvement in research for evidence-based planning and evaluation. Nepal, one of the fast urbanizing countries in South-East Asia faces large number of urban health problems.

Conclusions: Though numbers of cities and city dwellers are increasing rapidly, Nepal lacks healthy city projects and networking. The approaches of healthy city Wonju might be useful for developing countries such as Nepal to initiate and develop healthy cities projects in a sustainable way. 


\section{INTRODUCTION}

\section{Concept of healthy city}

The World Health Organization (WHO) defines a healthy city as one that is continually creating and improving physical and social environments, and expanding community resources that enable people to mutually support each other in performing all the functions of life and to reach their maximum potential ${ }^{1}$. Currently, more than $50 \%$ of the world's population lives in urban areas, and it is estimated that $70 \%$ of the world's population will be living in towns and cities by 2050; Africa and Asia are urbanizing faster than the other regions ${ }^{2,3}$. The healthy city approach is becoming increasingly important in addressing a large number of urban health problems arising due to urbanization and globalization in both developed as well as developing countries. "Make cities inclusive, safe, resilient and sustainable" is one of the goals of sustainable development (SDGs) ${ }^{4}$. This is the first time that cities have been prioritized on the global development agenda. Municipal and local Governments have the ability to act on urban health issues in a responsive manner to make a significant impact at national and global level ${ }^{5}$.

Health challenges particularly obvious in cities relate to water, environment, violence and injury, noncommunicable diseases (NCDs), unhealthy diets, physical inactivity, harmful use of alcohol, and outbreak of diseases. Participation in physical activity is obstructed by a variety of urban factors including overcrowding, high-volume of traffic, heavy use of motorized transportation, poor air quality, and lack of safe public spaces and sports facilities ${ }^{2}$. On the other hand, acting on urban health inequities requires the involvement of organized communities and all levels of Government; local, and national ${ }^{6}$.

Healthy cities program is a long-term international development initiative that aims to place health on the agendas of decision makers and to promote comprehensive local strategies for health protection and sustainable development through community participation, empowerment, intersectoral partnership, and equity. Healthy cities projects, starting in 1986, first were launched in developed countries; developing countries also started to implement around 1994. A healthy city aims to create a health-supportive environment, to achieve a good quality of life, to provide basic sanitation and hygiene needs, and to supply access to health care ${ }^{7}$.

\section{The healthy city Wonju project}

In Korea, the healthy cities project was started in Kwachon in $1998^{8}$. Since then, Korea has developed a unique program for healthy cities; it has developed a healthy city act, a health impact assessment program, an award system, and domestic networking system. A bottom-up approach for the development of healthy city policies and plans is promoted ${ }^{9}$. The healthy city Wonju project started in 2004 joined the alliance for healthy cities (AFHC) as a founding member in the same year, and announced the healthy city Wonju declaration in $2005^{10-12}$. In 2006, the project succeeded in launching its five-year plan; executed between 2006 and 2010. Wonju City joined the Korea Healthy Cities Partnership (KHCP) as a founding member in 2006. The indicators and home page with database have been developed to monitor and evaluate the program implementation since 2006. A 10 year long-term plan, vision 2020 (2011-2020) is currently being implemented, and will run until $2020^{11,12}$. Recently, Wonju City organized the seventh global conference of the AFHC, running from 29 $9^{\text {th }}$ August to $1^{\text {st }}$ September 2016, in Wonju. About 550 participants attended the conference from more than 50 cities over 15 countries and two administrative regions. The main theme of the conference was our cities, our health, our future ${ }^{13}$.

\section{Rationale of healthy city projects in developing countries}

While the current sustainable cities debate focuses on the problems for the world's largest urban settlements, the majority of all urban dwellers continue to reside in far smaller urban settlements ${ }^{14}$. If rapid urbanization focuses only on short-term economic development rather than sustainability, the situation is likely to lead down development paths that exacerbate global climate change, with a wide range of negative implications for global health and health equity. The decisions taken by cities in developing countries should support a preventive environmental health agenda and a goal of promoting health and well-being ${ }^{15}$. There is a considerable need of interventions such as the healthy cities project in developing countries ${ }^{16}$.

In the South-East Asia Region, the healthy cities Initiative was launched in 1994 with some cities of Bangladesh (Chittagong, Cox's Bazar, Rajshahi), Thailand (Bangkok), Sri Lanka (Badula), Nepal (Kathmandu), India (New 
Delhi); a comprehensive review of the program was carried out in 1998, and a healthy cities framework for action was developed for the region in 199917,18. Review studies show that the slow progress in developing healthy cities was due to unclear concepts among local authorities, lack of coordinated urban infrastructure and lack of community participation, preventive services being a low Government priority, and poor empowerment of local Government ${ }^{17,19}$.

Nepal is a developing country situated in South-East Asia with a human development index of 0.548 , and a life expectancy of 69.6 years $^{20}$. Nepal has a total population of 28 million, with an average annual population growth rate of $1.35 \%$. Estimated per capita GDP is $762 \$$, with a GDP growth rate of 3.04 for the year of $2014 / 2015^{21,22}$. Nepal currently has 217 municipalities and 3157 village development committees. An increasing number of municipalities indicates the rapid urbanization in Nepal; there were 58 municipalities until 2014, 133 new municipalities were established in 2014, and 26 were added in 2015 . About $30 \%$ of the total population has been living in municipalities ${ }^{21,47}$.

The objective of the current study is to review initiation, implementation, approaches, and achievements of the healthy city Wonju project as a case; and discuss the relevance of healthy city projects in cities in Nepal.

\section{METHODS}

Primarily, the study is a review-based case study of the healthy city project executed in Wonju city, Gangwon Province, Korea. We extensively reviewed the literature and web pages relating to the healthy city Wonju project. Most of the information we obtained from relevant published articles and homepage of healthy city Wonju, and the proceedings of the seventh global conference of the AFHC. We also searched online website for appropriate information from Korean Statistical Information Service (KOSIS), AFHC, and WHO publication. In addition, we reviewed published articles and documents related to healthy city projects in developing countries. For additional relevant information, we searched the website of the Central Bureau of Statistics (CBS) of Nepal, project report of Asian Development Bank (ADB) and National Nepalese News papers.

\section{RESULTS}

\section{Wonju city profile}

Korea is located on the East Asia, Southern Korean peninsula. The total population of Korea is 51,649,552 as of August 2016, with an annual fertility rate of 1.24 , and a life expectancy of 82 years $^{23,24}$. Wonju City, located in central Korea, in the South West of the Gangwon province is approximately 140 kilometers East of Seoul, and has a total area of 867.76 per square $\mathrm{km}^{25}$. It is the biggest city in Gangwon-do; it has a total population of 330,134, with 164,246 males, and 165,888 females, and has a fertility rate of $0.8 \%$ (Table 1$)^{26}$.

Table 1: Demographic profile of Wonju city

\begin{tabular}{ll}
\hline Indicators & Magnitude \\
\hline Size & $867.76 \mathrm{~km}^{2}$ \\
Total population & 330,134 \\
Males & 164,246 \\
Females & 165,888 \\
Population over 65 years & 39862 \\
Population growth rate & $0.8 \%$ \\
Population density & 380.4 persons $/ \mathrm{km}^{2}$ \\
Total area & $867.97 \mathrm{~km}^{2}$ \\
\hline
\end{tabular}

\section{The healthy city Wonju: History of development}

Korea has national guidelines, local Government acts and the Korea healthy city partnership (KHCP) for the implementation of healthy city projects. The Korean health promotion healthy city act plays a key role in healthy city project implementation ${ }^{9,27}$.

The healthy city Wonju project was initiated in 2004 by establishing a healthy city team and a healthy city advisory committee. It joined the AFHC as a founding member in the same year. The AFHC is an international network aiming at protecting and enhancing the health of city dwellers. The Alliance is a group of cities and other organizations that try to achieve the goal through an approach called "Healthy cities" in the close collaboration with the $\mathrm{WHO}^{10}$. In 2005, Wonju city announced the 'healthy city Wonju declaration' to give municipal commitment to make each citizen lead healthy and active life through healthy city Wonju. As founding member, it joined KHCP, national network of Korean healthy cities in 2006. In 2006, it initiated a five year plan (2006 - 2010), with the main objective of setting out systematic policies 
for healthy city projects through the effective investment of tobacco consumption tax. The plan generally focused on life style modification, disease prevention and rehabilitation, and setting healthy industry, infrastructure and environment ${ }^{11,12}$. The first plan of the healthy city was evaluated through a community survey and key informants' interviews. Both processes as well as output indicators were used. The SPRIT checklist was used for the process evaluation ${ }^{28}$. Vision 2020, a 10-year plan (2011 - 2020), includes two approaches: An individual approach and a socio-environmental approach. The individual approach includes life style modification and diseases prevention, and rehabilitation. The socio-environmental approach comprises: Setting, infrastructure, environment, and health industries. Here, settings include healthy schools, healthy work places, healthy hospitals, healthy communities, healthy markets and food safety, and healthy farming villages. Infrastructure includes transportation, culture and welfare, and safety and social marketing. Environmental planning and environmental education are included under environment. Advanced health technology, smart healthy city, and health tourism are included in health industries ${ }^{11,12}$. These priorities were decided after collecting and analyzing the responses from healthy city experts and Government officials ${ }^{29}$. The chronological development events are shown in Table 2.

Table 2: Historical development of healthy city Wonju

\begin{tabular}{ll}
\hline Contents & Year \\
\hline Starting of healthy city Wonju project & 2004 \\
Joining the AFHC & 2004 \\
Announcement of “Declaration of healthy & 2005 \\
city Wonju” & \\
Joining KHCP & 2006 \\
Enactment of healthy city advisory & 2005 \\
committee & \\
$\begin{array}{l}\text { Development of first five year plan (2006 - } \\
\text { 2010) }\end{array}$ & 2006 \\
$\begin{array}{l}\text { Development of 10-year plan, "Vision 2020" } \\
\text { Organization of “the seventh global }\end{array}$ & 2010 \\
conference of the AFHC” & 2016 \\
\hline
\end{tabular}

\section{Examples of healthy city projects of Wonju city}

Several setting oriented healthy city projects were conducted by citizens between 2011 and 2016; 25 were supported by the city. Most of the activities were focused on health promotion, such as establishing physical activity clubs, gardening, and food education ${ }^{12}$. Table 3 shows some examples of healthy city projects of Wonju city.

Table 3: Healthy city projects of Wonju city

\begin{tabular}{|c|c|}
\hline Name of the projects & Interventions \\
\hline $\begin{array}{l}\text { 1. Sport and medicine } \\
\text { center: Evidence- } \\
\text { based }\end{array}$ & $\begin{array}{l}\text { Physical checkup, exercise } \\
\text { prescription, health education }\end{array}$ \\
\hline $\begin{array}{l}\text { 2. Environment- } \\
\text { friendly streamside } \\
\text { park }\end{array}$ & $\begin{array}{l}\text { Construction of a flood-control } \\
\text { dam, and providing various } \\
\text { themed spaces }\end{array}$ \\
\hline 3. Culture street project & $\begin{array}{l}\text { Cultural space for citizens and } \\
\text { pedestrians with amenities: } \\
\text { Installation of fountains, land } \\
\text { purchased for performance } \\
\text { spaces, and building purchased } \\
\text { for exhibitions }\end{array}$ \\
\hline $\begin{array}{l}\text { 4. Climate change } \\
\text { response education } \\
\text { and research center }\end{array}$ & $\begin{array}{l}\text { Education and research center } \\
\text { Renewable energy exhibition } \\
\text { facility }\end{array}$ \\
\hline 5. Walkable city & $\begin{array}{l}\text { Safe road for both drivers and } \\
\text { pedestrians: One-way traffic } \\
\text { with three lanes, underground } \\
\text { distribution line and pedestrian } \\
\text { path extension }\end{array}$ \\
\hline
\end{tabular}

\section{Monitoring and evaluation}

The Project has developed its own indicators, database, and monitoring system. The database includes information regarding demographic, health status, life style, physical and social infrastructure, and socioeconomic status ${ }^{11}$. The database was developed in 2006 and updated in 2009. The evaluation of web database quality was performed; some indicators were added and some were deleted from web database for the better management of information based on the finding of the study ${ }^{30}$. A comparative study of healthy cities, Liverpool in England and Wonju in Korea showed that fifteen of twenty-five programs were similar, and Wonju mostly used quantitative analysis with some qualitative analysis for the evaluation and vice versa in Liverpool ${ }^{28}$.

\section{Awards for good practice}

The WHO and the AFHC recognize and award outstanding work in certain defined areas to encourage cities to 
innovate and establish effective and efficient ways of promoting and protecting the health of urban populations. Based on the good practice, Wonju city has been awarded for the following works (Table 4) ${ }^{10,12}$.

Table 4: Awards for good practice

\begin{tabular}{lll}
\hline Year & Awards & Organizations \\
\hline 2008 & $\begin{array}{l}\text { Good practice award : } \\
\text { Comprehensive no-smoking } \\
\text { program }\end{array}$ & WHO \\
2008 & $\begin{array}{l}\text { Best proposal award : Climate } \\
\text { change and response }\end{array}$ & WHO \\
2010 & $\begin{array}{l}\text { Good practice award: Physical } \\
\text { activities }\end{array}$ & WHO \\
2010 & $\begin{array}{l}\text { Creative development award: } \\
\text { Evaluation of Healthy City }\end{array}$ & AFHC \\
2008 & $\begin{array}{l}\text { Good Dynamic Award } \\
\text { Good Practice Award: Safe city }\end{array}$ & WHO \\
2012 & $\begin{array}{l}\text { Good Practice Award: Woman } \\
\text { friendly city }\end{array}$ & WHO \\
Good Practice Award: Out of & WHO \\
& school youth & \\
\hline
\end{tabular}

\section{Investing tobacco tax for healthy city}

Wonju is the first municipality in the Republic of Korea to fund the healthy city project through collection of the local tobacco consumption tax. For effective collection and allocation of the tobacco consumption tax, strong leadership from local authorities, particularly from the Mayor, was found to be the most important element in securing tobacco consumption tax revenues to fund the healthy cities Initiative ${ }^{9,31}$. The healthy city Wonju is sustainably financed by the revenues collected from local tobacco consumption tax, which has legal approval from the city council ${ }^{9}$. At present (2015), 34\% of the total budget for the healthy city Wonju project comes from tobacco consumption tax, whereas it was 59\% in 2010. Its discrepancy is due to the total budget for the project being doubled by city administration in $2015^{12}$.

\section{Strong political commitment}

In Korea, healthy city projects have been voluntarily initiated by local Governments. Support from the central Government and funding from the health promotion fund is supposed to boost the projects. One study conducted to find the challenges of healthy city projects in Korea stated three main challenges that the head of the city should commit to healthy city projects to succeed: investing more funds and human resources in projects, local government should provide administrative support to implement multi-sectoral collaborative projects, and central Government should encourage and support local Government's healthy city projects. The healthy city Wonju project is under the stewardship of Wonju city hall $^{12,32}$.

\section{Collaboration with Universities}

Since 2004 , the project has been working in collaboration with the Yonsei healthy city research center for evidence based planning and execution ${ }^{12}$. The healthy city Wonju project has published scientific articles in different national and international journals collaborating with the healthy city research center. It helps the project in Wonju, as well as those in other cities, with evidence based planning, implementation and, evaluation of projects $^{9,28,30-32}$.

\section{Innovative and enterprise city}

Wonju city has stated new concept as innovative and enterprise city since 2010, based on the concept of the healthy city. The innovative city zone comprised of headquarters of the national health insurance service, health insurance review and assessment service, Red Cross society, and the national forensic service in Wonju city. Enterprise city has built medical device complex in Wonju ${ }^{12}$.

\section{Healthy city program in Nepal: Situation and possibilities}

The Bangkok declaration held in 2010 on 'Urbanization and health' recommended member states of South-East Asian region to tackle urbanization and health using healthy city approaches, which focuses intersectoral collaboration and an increased role of municipalities in ensuring infrastructures for health and development ${ }^{33}$. Some cities such as Delhi (India), Bangkok metropolitan administration and Phanat Nikhom town municipality (Thailand), Jakarta (Indonesia) have already implemented healthy city approach to address the urban health problems and inequality in health ${ }^{34}$.

Nepal is experiencing 3.18\% rate of urbanization (2010 - 2015) annually. The population density of Nepal is estimated to be 180 persons per $\mathrm{km}^{2}$ with urban population density of 693 persons per $\mathrm{km}^{2}$. However, some municipalities have high population densities; the population density of the top five municipalities is more 
than 6000 persons $/ \mathrm{km}^{2}$ including 19726 persons $/ \mathrm{km}^{2}$ in Kathmandu metropolitan area ${ }^{21}$. Most of the cities in Nepal are facing challenges of safe drinking water, sanitation facilities and waste management, limited access to quality health services; slum and squatters settlements ${ }^{34}$. According to the global burden of disease study 2015, Nepal is at $158^{\text {th }}$ rank of 188 countries. Health-related SDGs indicators such as hygiene, water, disaster, occupational risk burden, mean PM 2.5, malaria, air pollution mortality, road injuries, household air pollution, and sanitation shows very low status in Nepal. For achievement of health-related SDGs, Nepal needs to invest to improve basic living condition of the citizens ${ }^{35}$.

The Ministry of urban development created in 2012 is responsible for urban planning; developing and managing basic urban infrastructure and services such as water supply, sanitation, solid waste management; and housing ${ }^{36}$. Recently, national urban health policy 2015, developed by Ministry of Health, got final legal approval; and the development of urban health strategy is on the process $^{37}$. ADB have supported some municipalities to implement urban development program, for example, "Nepal Cities: Clean and healthy urban development", a project implemented with ADB support in Bharatpur municipality, one of the fastest growing municipalities. The project established in 2005 promoted sustainable urban development through better municipal planning and upgrading of infrastructure for clean water supply, drainage, and sanitation ${ }^{38}$.

In spite of such efforts, cities in Nepal has not initiated and developed healthy city projects, have not created any national networking system or joined international networks of healthy cities as per the concept, except few initial programs that were implemented in the Kathmandu valley $^{10,17,39}$.

\section{DISCUSSION}

In the era of sustainable development, "if cities do not act, the SDGs will not be achieved". The WHO Regional Director for the Western Pacific Region stated that a city must do to be a healthy city: It need to focus on the poorest and most vulnerable, address water and sanitation, manage municipal waste; create resilient health facilities; preserve green spaces and heritage sites, plan for clean air; encourage physical activities and other healthy behaviors ${ }^{40}$.
Since the official initiation of healthy city projects by WHO in Europe in 1986, the healthy cities movement has spread across the six WHO regions, thousands of cities worldwide are part of the healthy cities network and exist in all WHO regions ${ }^{7}$. WHO has developed guidelines for establishing healthy city projects in low income countries in 1995, and it aims to develop role of local government in public health and encourage them to implement health for all policy at city level ${ }^{39}$. However, the effectiveness of healthy cities has largely been confined to industrialized countries $^{41}$.

A key political challenge to urban health development is the general weakness of municipal structures in SouthEast Asian Region ${ }^{19,42}$. A study evaluating healthy city projects in developing countries shows that there was limited political commitment to the projects, perhaps due to the fact that most of the municipalities had not requested the projects ${ }^{43}$. In contrast to this, the healthy city Wonju project is under the stewardship of the Wonju city administration. An evaluation study states that Wonju city was equipped with the resources, plans, infrastructure, cooperative organizations, and the healthy city networks, enabling the consistent implementation of the project based on strong political commitment ${ }^{44}$. The lesson from this case of Wonju, is that the involvement and leadership of municipality in collaboration with cooperative organization and comprehensive planning may improve urban health and living environments. There is a need to generate political commitment and community participation in preparing and implementing a municipal health plan; to increase awareness of health issues in urban development efforts by municipal and national authorities; and to create a network of cities that promotes information exchange and technology transfer. An evaluation study of healthy cities projects conducted in 2002 in cities in India, Nepal, Sri Lanka, and Thailand indicated that the exposure and commitment of decisionmakers, particularly local politicians; clarity of vision and mission, with a strong planning and management team; sense of ownership of policies; high degree of stake holder involvement; and institutionalization of healthy cities programs, are the factors contributing to successful implementation ${ }^{18}$.

Community participation is an essential part of the process of good local governance, and empowerment remains at the heart of effective health promotions. These processes must be seen as fundamental values of healthy 
cities and so must be developed as an integral part of long-term development ${ }^{42}$. Even though health is the entry point of the healthy cities approach, its underlying rationale has always been based on a model of good urban governance, which includes political commitment, intersectoral planning, city wide partnerships, community participation, and monitoring and evaluation ${ }^{41}$. The healthy city Wonju is not limited to the public health field; it emphasizes the concept of health in the overall planning of urban developments. The 'Vision 2020' plan for Wonju has established multiple programs, including infrastructure development; health promotion, disease prevention, and rehabilitation, welfare; and improvement of the physical environment and health industries ${ }^{9,11,12}$.

Tobacco consumption tax has a dual advantage: Tobacco controlling strategy and a sustainable funding source for healthy city projects ${ }^{31,45}$. As the healthy city Wonju project is being financed in a sustainable way through the revenues collected from tobacco consumption tax, cities in Nepal could adopt this strategy to reduce the prevalence of tobacco consumption and fund healthy city initiatives ${ }^{31,46}$. Healthy cities principles are drawn on the social determinants of health, such as improvements in living and working conditions, public education, medical science, democratic governance, public health practices, and human rights ${ }^{41}$. The socio-demographic, economic, political and cultural backgrounds of countries vary greatly, which may influence the implementation of healthy city projects. However, the approaches used by the healthy city Wonju, such as securing the leadership of local Government; sustainable financing from local resources; participation of cooperating community organizations; multi-sectoral approaches may be effective strategies for many developing countries hoping to move forward with healthy city initiatives. Thus, the healthy city movement can contribute toward promoting health as well as urban development through healthy city networks between cities and countries.

\section{CONCLUSIONS}

The healthy city Wonju project has been continuing since 2004 under theleadership of the Wonju city administration in collaboration with the healthy city advisory committee, and Yonsei healthy city research center. The project carries out a variety of activities promoting the health of citizens and sustainable city development, based on both individual and socio-environmental approaches. In the last 10 years, Wonju city has been awarded for its good practice on different areas by the WHO and the AFHC. The approaches of the healthy city Wonju project included: The strong political commitment of local Government, funding from tobacco consumption tax, partnerships with Universities, a well-organized healthy city team under city administration, community participation through cooperative organizations, comprehensive multisectoral planning, coordination with the AFHC and KHCP and involvement in research activities for evidence based planning. Such strategies maybe useful and crucial for developing countries like Nepal to tackle the existing urban health and development problems by initiating and developing healthy city initiatives.

\section{REFERENCES}

1. WHO. Healthy cities. Health Promotion Glossary. 1998. Available at http://www.who.int/healthy_settings/ types/cities/en/ [Accessed 22 August, 2016].

2. WHO. Urbanization and health. Bull World Health Organ. 2010a; 88: 245-246.

3. UN (United Nations), 2014. World urbanization prospects, the 2014 revision. New York: United Nations, Department of Economic and Social Affairs, Population Division. Available at https://esa.un.org/ unpd/wup/ [Accessed 17 September, 2016].

4. UN (United Nations). Sustainable development goals. 2015. Available at https://sustainabledevelopment. un.org/sdg11[Accessed 13 September, 2016].

5. WHO and UNHABITAT. A global report on urban health: Equitable and healthier cities for sustainable development. 2016. Available at http://www.who. int/ kobe_centre/measuring/urban-global-report/ en/ [Accessed 17 September, 2016].

6. WHO and UNHABITAT. Hidden cities: Unmasking and overcoming health inequities in urban settings. 2010. Available at http://www.who.int/kobe_centre/ publications/ hidden_cities_ex2010/en/ [Accessed 18 September, 2016].

7. WHO. Healthy Setting - Healthy Cities. 2016. Available at http://www.who.int/ healthy_settings/ types/ cities/en/ [Accessed 24 August, 2016].

8. Kim HJ. Healthy City Kwachon 21 Project: A community health promotion program in Korea. Asia Pa J Public Health. 2000; 12: S67-70. 
9. Moon JY. Nam EW, Dhakal S. Empowerment for Healthy Cities and communities in Korea. J Urban Health. 2014; 91(5): 886-893.

10. Alliance for Healthy Cities. 2016. Available at http:// www.alliance-healthycities.com [Accessed 12 Sept, 2016].

11. Healthy City Wonju. Healthy City Wonju. 2016. Available at http://healthycity.wonju.go.kr/hb/en [Accessed 9 September, 2016].

12. Nam EW. History, present and future of healthy city Wonju. The $7^{\text {th }}$ Global Conference of the AFHC Proceedings - Plenary Sessions II, 29 August 1 September, 2016; Wonju, Republic of Korea. Available at http://afhc2016.wonju.go.kr/material/ proceedings.php [Accessed 13 September, 2016].

13. Wonju City, 2016a. The $7^{\text {th }}$ Global Conference of the AFHC, August 29 - September 1, 2016; Wonju Republic of Korea. Available at http://afhc2016. wonju.go.kr/ [Accessed 9 September, 2016].

14. Cohen B. Urbanization in developing countries: Current trends, future projections, and key challenges for sustainability. Technology in Society. (2006); 28(1): 63-80.

15. Campbell-Lendrum D, Corvalan C. Climate change and developing-country cities: Implications for environmental health and equity. J Urban Health. 2007; 84(1): 109-117.

16. Harpham T. Urban health in developing countries: What do we know and where do we go? Health Place. 2009; 15(1): 107-116.

17. WHO. 2000. Regional office for South-East Asia. Strengthening healthy city project in South-East Asia. An opinion survey.

18. WHO. 2003. Healthy cities around the world. An overview of the healthy cities movement in the six WHO regions. 2003. Available at http://www.euro. who.int/_data/assets/_pdf_file/0015/101526/ healthycityworld.pdf [Accessed 24 August, 2016].

19. Aggarwal S, Yoosuf AS. Urbanization dynamics and WHO's "healthy city" initiatives in the South-East Asia Region. Regional Health Forum. 2010; 14(1): 25.

20. UNDP (United Nations Development Program). Human Development Report. 2015. Available at http://hdr.undp.org/sites/default/files/2015_ human_development_report.pdf [Accessed 17 Sept, 2016].

21. CBS (Central Bureau of Statistics). Population Monograph of Nepal. 2014. Government of Nepal. Available at http://cbs.gov.np/sectoral_statistics/ population/ populationmonographnepa_2014 [Accessed 18 Sept, 2016].

22. CBS (Central Bureau of Statistics). Nepal in Figure. 2015. Government of Nepal. Available at http://cbs. gov.np/publications/Nepal_Figure_2015[Accessed 17 September, 2016].

23. KOSIS (Korean Statistical Information Service). 2016a. Available at http://rcps.egov.go.kr:8081/jsp/ stat/ppl_stat_jf.jsp [Accessed 13 September, 2016].

24. KOSIS (Korean Statistical Information Service). 2016b. Available at http://kosis.kr/eng [Accessed September 13, 2016].

25. Wonju City. 2016b. Introduction of Wonju. Available at http://www.wonju.go.kr/site/language/eng/ page/sub01_02.jsp [Accessed 19 September, 2016].

26. KOSIS (Korean Statistical Information Service). 2016c. Available at http://stat.kosis.kr/statHtml_ host/statHtml.do?orgId=652\&tblId=DT_003_01\&db User=NSI_IN_652[Accessed 13 September, 2016].

27. Nam EW, Engelhardt K. Health promotion capacity mapping: The Korean situation. Health Promotion Int. 2007; 22(2): 155-162.

28. Kang SH, Nam EW, Moon JY. A Comparative study of healthy city project evaluation in UK and Korea: Focusing on Liverpool city and Wonju city. Korean J Health Edu Promot. 2013; 30(2): 93-103.

29. Park MB, Nam EW, Lee HJ, Shin TS. A study of priority setting of healthy city project indicators with the use of AHP model. Korean J Health Ed Promot. 2008; 25(3): 139-151.

30. Nam EW, Park JS, Choe EH, Kim GN. A Study on the application of web database for healthy city Wonju. Korean J Health Service Management. 2012; 6(1): 219-229.

31. Nam EW, De Leuw E, Moon JY, Nayu I, Dorjsuren B, Park MB. Sustainable funding of health initiatives in Wonju, Republic of Korea via a tobacco consumption tax. Health Promot Int. 2011; 226(4): 457-64. 
32. Nam EW, Lee A, Moon JY, Song YLA, Dhakal S. Analyze the characteristics of the healthy cities projects using HP-Source. net in Korea. Int J Health Promot Edu. 2015; 53(5): 244-256.

33. WHO. 2010b. Bangkok declaration on urbanization and health. Available at http://apps.searo.who.int/ pds_docs/B4827.pdf [Accessed 19 October, 2016].

34. WHO. 2012. Urban health equity assessment and intersectional responses. Report of the Regional Workshop WHO Regional Office for South-East Asia, 27-29 November, New Delhi, India. Available at http://apps.searo.who.int/PDS_DOCS/B5092.pdf [Accessed 19 October, 2016].

35. Lim SS, Allen K, Bhutta ZA, Dandona L, Forouzanfar $\mathrm{MH}$, Fullman $\mathrm{N}$ et al. Measuring the health-related sustainable development goals in 188 countries: A baseline analysis from the global burden of disease study 2015. Lancet. 2016; 388(10053): 1813-1850.

36. Bakrania S. Urbanization and urban growth in Nepal. 2016 Available at http://www. gsdrc.org/wpcontent/uploads/2015/11/HDQ1294.pdf [Accessed 19 October, 2016].

37. HERD (Health Research and Social Development Form). 2016. From Agenda to Action: Urban Health Policy Development in Nepal. Available at http://herd. org.np/content/agenda-action-urban-health-policydevelopment-nepal [Accessed 19 October, 2016].

38. Asian Development Bank (ADB). 2013. Nepal cities: Clean and healthy urban development. Available at https://www.adb.org/results/nepal-cities-cleanand-healthy-urban-development [Accessed 17 October, 2016].

39. WHO. 1995. Building a healthy city: A-step by-step approach to implementing healthy city projects in low-income countries. Geneva, Switzerland.
40. Shin YS. Sustainable development for our cities, our health and our future. 2016. The 7th Global Conference of the AFHC Proceedings-Key note Sessions. 29 August - 1 September, Wonju, Republic of Korea. Available at http://afhc2016.wonju.go.kr/ material/ proceedings.php [Accessed 13 September, 2016]

41. Awofeso N. The healthy cities approach: Reflections on a framework for improving global health. Bull World Health Organ; 2003; 81(3): 222-223.

42. Heritage Z, Dooris M. Community participation and empowerment in healthy cities. Health Promot Int. 2009; 24(suppl 1): i45-i55.

43. Harpham T, Burton S, Blue I. Healthy city projects in developing countries: The first evaluation. Health Promot Int. 2001; 16(2), 111-125.

44. Nam EW, Moon JY, Lee A. Evaluation of healthy city project using SPIRIT checklist: Wonju city case. Korean J Health Edu Promot. 2010; 27(5) ; 15-25.

45. Do YK, Park K. Local governments' dependence on tobacco tax revenue: A deterrent to tobacco control in the Republic of Korea. Bull World Health Organ. 2009; 87(9): 692-699.

46. Sreeramareddy CT, Ramakrishna reddy N, Kumar HH, Sathian B, Arokiasamy JT. Prevalence, distribution and correlates of tobacco smoking and chewing in Nepal: A secondary data analysis of Nepal Demographic and Health Survey-2006. Subst Abuse Treat Prev Policy. $2011 ; 6(1): 1$.

47. Thapa G. Government declares 26 new municipalities. Kathmandu Post. 19 September, 2016. Available at http://kathmandupost.ekantipur.com/news/201509-19/govt-declares-26-new-municipalities.html [Accessed 26 August, 2016]. 